\title{
Fragmentação da luta política e agenda de desenvolvimento ${ }^{1}$ / Fragmentation of the political struggle and the development agenda
}

Resumo: O papel da democracia na representação dos interesses gerais da sociedade foi mitigado, nas últimas quatro décadas, da concorrência capitalista sob a hegemonia do capital financeiro e do pensamento neoliberal. O papel que se espera dos partidos políticos progressistas, como instituiçôes articuladoras das demandas da sociedade numa perspectiva de transformação, foi esvaziado. $\mathrm{O}$ ataque ao poder dos sindicatos, protagonista das transformaçóes sociais no capitalismo, também foi um dos focos da investida neoliberal. Em função desses fatos, nas últimas décadas, o campo progressista deixou de tratar dos grandes temas nacionais relacionados ao enfrentamento do subdesenvolvimento político, econômico e social do país. A fragmentação da luta política em torno de pautas setoriais específicas tem prevalecido ante o debate de temas estruturais. Com raras exceçóes, perdeu-se a perspectiva de que o encaminhamento de muitas dessas pautas segmentadas depende de superarem-se constrangimentos estruturais políticos e econômicos pensados na ótica de um novo projeto de transformação.

1 Texto elaborado como contribuiçấo para o debate promovido pelo Movimento da Reforma Sanitária Brasileira, integrado por várias entidades que historicamente atuam em defesa da saúde coletiva no Brasil. O autor agradece as críticas e sugestōes de Eli Iola Gurgel Andrade, Fernando Nogueira Costa, Joaquim Soriano, Jorge Mattoso, Lena Lavinas, Luis Eugenio Portela Fernandes de Souza, Marcio Pochmann, Nelson Rodrigues dos Santos, Silvio Caccia Bava, Tatiana Santos, Wilson Cano e Wladimir Pomar, feitas à versão preliminar deste ensaio.

2 Economista, professor do Instituto de Economia da Unicamp, pesquisador do Centro de Estudos Sindicais e do Trabalho (Cesit) e coordenador da rede Plataforma Política Social Agenda para o Desenvolvimento <www.plataformapoliticasocial.com>. 
Em última instância, os protestos populares de junho de 2013 repuseram o conflito redistributivo no centro do debate nacional. As respostas não podem ser minimalistas, mas pensadas na perspectiva de um projeto de transformação. O desafio do campo progressista é ampliar os diálogos na perspectiva de construir consensos para a formulação de um projeto nacional nucleado no combate às diversas faces das desigualdades sociais, o que demanda a construçáo de um campo de alianças e debates públicos cada vez mais ampliados. Este ensaio sugere pontos de uma agenda sobre a dimensão social do desenvolvimento. Essa via poderá abrir pistas para que a luta política se liberte dos labirintos em que está enredada.

Palavras-chave: desenvolvimento; distribuição da renda; desigualdades sociais; Estado de Bem-Estar Social.

Abstract: The role of democracy in the representation of the general interests of society was mitigated, in the last four decades, from the capitalist concurrence under the hegemony of the financial capital and the neoliberal thought. The role expected by the progressive political parties, as articulator institutes of the demands of society in a perspective of transformation, was dumped. The attack on the power of trade unions, protagonists of the social transformations in capitalism, was also one of the neoliberal assault outbreaks. Due to these facts, in the last decades, the progressive field stopped working on major national issues to face the political, economic and social underdevelopment of the country. The fragmentation of the political struggle on specific guidelines has prevailed compared to the debate on structural themes. With rare exceptions, there was a loss in the perspective that the addressing of many of these targeted guidelines depend on the political and economic structural constraints overtake conceived from the viewpoint of a new project of transformation. Ultimately, the popular protests of June 2013 replaced the redistributive conflict in the center of national debate. The answers cannot be minimalistic, but they need to be thought in the perspective of a transformation project. The challenge of the progressive field is to expand the dialogue in the perspective to build consensus for the formulation of a nucleated national project to combat the numerous aspects of social inequalities, which 
requires the construction of an alliance field and public debates increasingly enlarged. This essay suggests points of an agenda on the social dimension of development. This path may open tracks for the political struggle to be released from the mazes in which it is entangled.

Keywords: development; income distribution; social inequalities; Welfare State.

ste artigo tem por objetivo ressaltar a importância da construção
coletiva de um projeto de transformaçáo que deveria servir como referência para a luta política no Brasil neste início do século 21. Isso porque, nas últimas décadas, o campo progressista deixou de tratar dos grandes temas nacionais relacionados ao enfrentamento do subdesenvolvimento político, econômico e social do país. A fragmentação da luta política em torno de pautas setoriais específicas tem prevalecido ante o debate de temas estruturais. Com raras exceçóes, perdeu-se a perspectiva de que o encaminhamento de muitas dessas pautas segmentadas depende de superarem-se constrangimentos estruturais políticos e econômicos pensados na ótica de um novo projeto de transformação.

A segmentação de pautas tende a conduzir os diversos atores políticos para labirintos cujas portas de saída dificilmente serão encontradas. Partidos políticos, sindicatos, movimentos sociais e universidades parecem viver enredados e prisioneiros de seus próprios labirintos (seção 1). Os protestos populares reabrem perspectivas promissoras para impulsionar a retomada do pensamento crítico sobre um projeto de transformação na perspectiva do desenvolvimento. $\mathrm{O}$ pano de fundo obscuro do mal-estar exposto pelas ruas parece guardar relaçóes com as múltiplas faces da crônica desigualdade social brasileira.

Se essa hipótese estiver correta, em última instância, os protestos repuseram o conflito redistributivo no centro do debate nacional. As respostas não podem ser minimalistas, mas pensadas na perspectiva de um projeto de transformação (seção 2). 
O desafio do campo progressista é ampliar os diálogos na perspectiva de construir consensos para a formulação de um projeto nacional nucleado no combate às diversas faces das desigualdades sociais, $\mathrm{o}$ que demanda a construção de um campo de alianças e debates públicos cada vez mais ampliados.

A última parte desse ensaio sugere pontos de uma agenda sobre a dimensão social do desenvolvimento. Essa via poderá abrir pistas para que a luta política se liberte dos labirintos em que está enredada (seção 3).

\section{Fragmentação da luta política}

O papel da democracia na representação dos interesses gerais da sociedade foi mitigado nas últimas quatro décadas da concorrência capitalista sob a hegemonia do capital financeiro e do pensamento neoliberal.

Com a hegemonia dos mercados desregulados, a política deixou de tutelar a economia. A sociedade perdeu capacidade de conter o ímpeto desagregador das forças de mercado. Existe clara assimetria na representação política, em favor dos interesses do poder econômico. A esfera pública foi esvaziada ante os valores do individualismo e da meritocracia. Os Estados nacionais foram enfraquecidos e perderam a capacidade de coordenar projetos de transformação. Forjaram-se cultura e ideologia retrógradas em relação ao desenvolvimento.

Para Hirsch (2013) “o capitalismo transformado em sentido neoliberal minou as bases da democracia liberal representativa” e ocorre "ampla submissão da sociedade civil e do Estado à economia". O objetivo exitoso da "grande contraofensiva neoliberal era criar um sistema político-econômico livre de interferências democráticas”. Estabeleceu-se "um sistema mundial de Constitucionalismo neoliberal" que, na prática, "retirou de cada Estado a possibilidade da influência política democrática". 
Nesse processo, o caráter do sistema político também sofreu modificações. O sistema fordista de "partidos populares", que aglutinavam amplos interesses sociais e procuravam influenciar os processos políticos decisórios, passou a ser "coisa do passado", aponta Hirsch. Esse modelo foi substituído pela ideia da "individualização", impulsionada pelos próprios partidos, pela qual o comportamento do mercado penetra em todas as áreas da vida, desde a família até as escolas e as universidades. O indivíduo como "empresário de si mesmo" torna-se a figura central das relaçóes sociais, afirma o autor. O desgaste da democracia parece ser generalizado em todo o mundo, desafiado pelo poder hegemônico dos interesses do grande capital financeiro.

No caso brasileiro, também é preciso levar em conta a "secular capacidade das elites, para preservarem o status quo social”, como ressaltada por Celso Furtado (1979, p. 1-2). Para o autor, o Brasil é um país "em que a miséria de grande parte da população não encontra outra explicação que a resistência das classes dominantes a toda mudança capaz de pôr em risco seus privilégios”. No golpe de 1964, a classe dirigente "apelou às forças armadas, a fim de que essas desempenhassem agora o papel de gendarme do status quo social, cuja preservação passava a exigir a eliminação da democracia formal”.

Nos anos da década de 1980, a manutenção desses privilégios foi novamente ameaçada pela força do movimento social. Após cambalearem num primeiro momento, as elites retomaram o fôlego, enterraram a emenda da eleição direta, voltaram ao governo com o novo pacto conservador de transição democrática, manipularam para evitar a vitória de Lula em 1989 e, a partir do ano seguinte, reassumiram suas cadeiras cativas no centro do poder. Passado o susto, conservados os privilégios, acataram o projeto liberal imposto pelos mercados, abrindo mão de alternativas e de graus de manobras para a resistência política e econômica.

Essa trajetória é emblemática da fantástica capacidade de mimetização de comportamentos detida pela classe política para representar os interesses do poder hegemônico (econômico, político, midiático) em 
cada conjuntura. Observe-se o paradoxo de políticos identificados com a ditadura coordenarem a transição democrática; ou ainda, o fato de que partidos políticos identificados com as marchas populares dos anos 1970 e 1980, alguns anos depois coordenarem a implantação do antagônico projeto neoliberal.

Esse quadro mais geral tem influenciado a ação dos movimentos sociais, partidos políticos e sindicatos do campo progressista. "Os partidos estão desengonçados, os movimentos sociais fracionados, os sindicatos aquém do espaço que lhes cabe", alerta a professora Maria da Conceição Tavares. ${ }^{3}$

O papel que se espera dos partidos políticos progressistas, como instituiçóes articuladoras das demandas da sociedade numa perspectiva de transformação, foi esvaziado, nas últimas décadas. Os partidos e o sistema político como um todo estão submetidos à mercantilização do voto, tornando-se dependentes das bancadas particularistas de toda espécie.

A crise do sistema partidário impóe limites ao presidencialismo de coalizão. O imperativo da conciliação de interesses políticos antagônicos limita a ação dos governos do Partido dos Trabalhadores na articulação das demandas da sociedade, identificadas com suas bandeiras históricas. Por sua vez, em geral, os partidos da esquerda radical desconsideram a correlação de forças e adotam posturas paralisantes, na medida em que a utopia socialista posterga iniciativas de transformação social para o futuro pós-capitalista.

$\mathrm{O}$ ataque ao poder dos sindicatos, protagonista das transformações sociais no capitalismo, também foi um dos focos da investida neoliberal. A partir do final dos anos 60 começou a haver certo incômodo com o poder dos sindicatos e com a interferência do Estado.

3 Maria da Conceição Tavares. Resistir para avançar. O resto é arrocho. Entrevista a Saul Leblon, Carta Maior, 11/06/2014. Disponível em: <http://www.cartamaior.com.br/?/ Editorial/Maria-da-Conceicao-Tavares-Resistir-para-avancar/31125>. 
"A primeira coisa que Reagan e Thatcher fizeram, foi derrotar os sindicatos". Esse foi o fator decisivo para impulsionar o neoliberalismo, aponta Belluzzo (2013b). De fato, o "ataque" aos direitos trabalhistas foi um dos núcleos da ofensiva dos mercados. "Na base de tal 'redirecionamento' estava a vontade de quebrar a espinha dorsal dos sindicatos e dos movimentos organizados da sociedade", afirma Draibe (1993, p. 92).

No Brasil, nos anos da década de 1990 - em decorrência das privatizaçôes, da reestruturação produtiva e da estagnação econômica - os sindicatos sofreram duros golpes e derrotas e foram forçados a adotar pautas defensivas. A recente recuperação da atividade econômica e do mercado de trabalho mitigou esse quadro. Não obstante, uma parte importante destes sindicatos foi capturada pela atuação do governo nos últimos anos, o que limitou uma postura mais agressiva. Em parte por isso, além das suas pautas corporativas, o movimento sindical também não recuperou sua capacidade de protagonizar os debates sobre os grandes temas nacionais e defender um projeto alternativo de sociedade.

Apenas como ilustração, observe-se que a correta pauta pelo "fim do fator previdenciário" mostra-se minimalista diante das ameaças à consolidação da seguridade social recorrentes desde 1989. O debate sobre esse tema deveria ser pensado na perspectiva mais ampla de se pressionar para que a Constituição da República seja cumprida nos dispositivos referentes à organização, financiamento e controle social. $\mathrm{O}$ momento requer que se questionem as desoneraçôes fiscais que estão corroendo as bases de financiamento da previdência, saúde, assistência social e do Fundo de Amparo ao Trabalhador (FAT). É hora de pressionar por mudanças na contabilização inconstitucional praticada pelo Ministério da Previdência e Assistência Social (MPAS) desde 1989, que não considera a previdência como parte da seguridade social; e que náo contabiliza as renúncias fiscais como fonte de receitas da previdência social. 
Esse enredo que acomete os partidos políticos e os sindicatos interfere na ação do movimento social em seu conjunto. Como se sabe, é da natureza destas mobilizações setoriais tratar de temas também setoriais ou específicos. Mas na ausência da ação mobilizadora dos partidos, observa-se a fragmentação das pautas de luta política em torno de questóes muito específicas. Em geral, perdeu-se a perspectiva de que pouco poderá ser feito em termos setoriais na ausência de um projeto de transformação.

Tomando-se novamente a seguridade social como exemplo, observe-se que, muitas vezes, os movimentos sociais ligados aos setores da saúde, previdência, assistência social e seguro-desemprego participam de disputas fratricidas na defesa de suas pautas, o que é paradoxal à luz do texto constitucional. Os movimentos sociais deveriam de forma unificada exigir o cumprimento da Constituição da República. Como se sabe, os arts. 194 e 195 organizam esses setores e suas fontes de financiamento de forma integrada, além de assegurar mecanismos de controle social (Conselho Nacional da Seguridade Social) que nunca foram implantados.

A academia também não escapa desta lógica. Em relação ao passado, sobretudo nos anos de 1950 a 1970, são poucos os trabalhos que debatem as questóes nacionais na perspectiva do desenvolvimento. A questão é complexa e reflete, em alguma medida, os valores do individualismo, da meritocracia e da produtividade que foram enraizados no seio das universidades.

\section{Protestos populares, desigualdades e conflito redistributivo}

Aparentemente há dois vetores que explicam as motivaçóes dos protestos populares de 2013 - amplificados pela violência policial. O primeiro é a crise da política e da democracia. Existe convergência de opinióes no sentido de que o sistema representativo monopolizado pelos partidos está "envelhecido e burocratizado" ${ }^{4}$ e os cidadãos não se

4 Consultar Altman (2013), Belluzzo (2013a), Nassif (2013) e Werneck Vianna (2013). 
sentem representados. A crise afeta todos os partidos políticos e o Poder Legislativo dos três entes federativos.

O segundo vetor é a crise da cidadania social percebida pela mercantilização e pelas lacunas das políticas sociais universais e urbanas que atinge feiçôes críticas nas grandes metrópoles (MARICATO, 2013). Em alguma medida, a insatisfação popular está sinalizando que os avanços recém-conquistados na inclusão de parcela significativa da população ao mercado de consumo, apesar de positivos, não são suficientes. Os protestos apontam que é preciso ir além e promover a inclusão pela cidadania; pedem direitos e não mercadoria; exigem serviços públicos de qualidade e não serviços regidos pelo lucro.

Em última instância, a mensagem "queremos escolas, hospitais, postos de saúde e serviços públicos com padrão Fifa" contesta os dogmas do Estado mínimo, enraizados no país pela ofensiva neoliberal nos anos da década de 1990, que vendem a ilusão de que bastam políticas focalizadas para alcançar-se o "bem-estar". Ao mesmo tempo, elas reforçam a visão de que o desenvolvimento requer os mesmos valores do Estado de Bem-Estar Social que foram formalmente inscritos na Carta de 1988.

A soberania popular parece querer acertar as contas com o passado. Um quarto de século depois, os cidadãos estão perguntando aos poderes Executivo e Legislativo dos três entes federativos: quando vamos cumprir o que reza a Constituição da República?

As respostas das autoridades dos três níveis de governo deram-se em torno de temas importantes, mas distantes da natureza estrutural dos problemas. Não se pode resumir a questão da saúde à falta de médicos, em uma conjuntura em que $45 \%$ dos brasileiros identificam a saúde como o principal problema do país. ${ }^{5}$ Da mesma forma, as ques-

5 Pesquisa Datafolha. Disponível em: <http://www.febrasgo.org.br/site/?p=8448>. 
tôes da educação e do transporte público vão muito além da falta de recursos e de problemas nas planilhas das tarifas, respectivamente.

O mais grave ocorreu no caso da reforma política. Após rejeitar a correta proposta do plebiscito, o Congresso Nacional simplesmente deu as costas para a soberania popular, para preservar o status quo social.

Essas duas faces do mal-estar escamoteiam o pano de fundo mais obscuro marcado pelas múltiplas faces da desigualdade social, histórica e crônica. As diversas insatisfaçóes latentes vieram à tona por razóes ainda desconhecidas, mas certamente influenciadas pela violência policial para conter as açóes do Movimento do Passe Livre, num contexto cultural influenciado pelas mídias sociais. Seja como for, em última instância, ao colocar o dedo nessa ferida, os protestos repuseram o conflito redistributivo no centro do debate nacional.

Isso porque as respostas exigem mudanças estruturais pensadas na perspectiva de um projeto de transformação mais amplo. Esse conflito superpõe questóes historicamente não enfrentadas e novas demandas colocadas pela sociedade em transformação nas últimas décadas. As velhas desigualdades têm raízes históricas herdadas do passado escravocrata (CARVALHO, 2001), do caráter específico do capitalismo tardio (CARDOSO DE MELLO, 1998) e da curta experiência democrática do século 20 (SKIDMORE, 1989; DREYFUSS, 1981).

A sociedade que lutou contra a ditadura instalada em 1964 queria acertar as contas com esse passado. Para isso escreveu a Constituição da República de 1988, que estabeleceu a democracia e consagrou as bases de um sistema de proteçáo social inspirado em valores do Estado de Bem-Estar Social (FAGNANI, 2005). Mas a notável capacidade para preservar o status quo social, que é apanágio das elites brasileiras, colocou em plano secundário, mais uma vez, a soberania popular.

A cidadania social consagrada pela Carta de 1988 introduziu uma nova face do conflito redistributivo em torno da disputa pelos 
fundos públicos. Essa disputa foi intensificada nos anos da década de 1990, quando se optou pela inserção subordinada do país no capitalismo globalizado.

Na primeira década do século 21, foram engendradas alternativas ao modelo que vinha sendo implantado, que resultaram na melhoria dos padrôes de vida da população. O "projeto social-desenvolvimentista" elaborado pelo Partido dos Trabalhadores (MERCADANTE; TAVARES, 2001) ganhou maior centralidade na agenda governamental a partir de meados da década passada e houve melhor conjugação entre objetivos econômicos e sociais. A economia cresceu e distribuiu renda, fato inédito da história recente. Caminhou-se no sentido da construção de um modelo econômico menos perverso que o padrão histórico.

Reconhecer esse fato, no entanto, não implica endossar a ideia de que foi implantado um "novo padrão de desenvolvimento". A visão de que os governos progressistas eleitos em diversos países da América Latina seriam "pós-neoliberais" (SADER, 2014), também deve ser observada com cuidado. É verdade que foi aberta uma nova etapa de lutas contra a hegemonia do mercado. Mas, apesar dessa marcha, o continente está muito aquém de "superar e virar a página do neoliberalismo".

Como sinaliza o historiador Perry Anderson, neste início de século o neoliberalismo "segue aprofundando seu poder no mundo". É verdade que, nesse cenário, de governos progressistas da América do Sul, o continente passou a ser portador de "uma esperança que não existe em nenhum outro lugar do mundo hoje”. Na sua visão, o Brasil está "na linha de frente" deste processo de abrir frestas para caminhar no "contrafluxo da ideologia mundial dominante". ${ }^{6}$

Em suma, apesar dos progressos recentes, as marcas profundas das desigualdades sociais não foram apagadas. Tem razão a direção nacional do Partido dos Trabalhadores (2014) que, ao apontar os dese-

6 O Brasil e a América Latina, segundo Perry Anderson, Carta Maior, 15/10/2013. 
jos da sociedade pela realização de "um conjunto de reformas estruturantes", faz referência à necessidade de se resgatarem as "reformas de base" propostas por João Goulart e interrompidas pelo golpe militar há 50 anos. É paradoxal que, passado meio século, as reformas política, bancária, tributária, administrativa, educacional, urbana e agrária ainda permaneçam na ordem do dia.

\section{A dimensão social de um projeto de transformaçáo para o século 21}

A diversidade e a complexidade dos temas estruturais a serem enfrentados pressupóem a formulação de uma agenda de transformação que consolide os progressos recentes, mas caminhe muito além.

É verdade que essa perspectiva é limitada pela correlação de forças amplamente favorável ao poder econômico. Da mesma forma, a democracia brasileira é um processo em construção e ainda prevalece na sociedade um caldo de cultura antidemocrático e favorável ao golpismo que tem sido explorado por lideranças políticas da oposição e por setores da mídia. É certo que enfrentar as velhas e as novas desigualdades exige que o conflito redistributivo favoreça a sociedade e a cidadania em detrimento do poder econômico, o que coloca limites à manutenção da tradicional política de conciliação entre interesses políticos opostos.

Também é verdade que, após quarenta anos da ofensiva neoliberal, falar em agenda de desenvolvimento é pregar no deserto. Não obstante, não parece haver outro caminho possível caso se queira, de fato, enfrentar as desigualdades sociais, pano de fundo do mal-estar contemporâneo.

Novos desafios ao pensamento estruturalista

Em linhas muito gerais, podemos dizer que o pensamento estruturalista latino-americano desenvolvido pela Comissão Econômica para a América Latina e Caribe (Cepal) priorizava a transformação 
estrutural da economia da base agrário-exportadora em urbano-industrial. Em última instância, a estratégia almejava a construção dos "estágios superiores da pirâmide industrial verticalmente integrada”. A industrialização era a única via possível para reduzir as assimetrias entre o centro e a periferia e superar o subdesenvolvimento. ${ }^{7}$

A profunda heterogeneidade estrutural do emprego e da estrutura produtiva era vista como um dos obstáculos ao pleno desenvolvimento das forças produtivas capitalistas. A concentraçáo da renda decorrente dessa heterogeneidade, bem como o excedente de mão de obra que se deslocava do campo para a cidade, limitava a demanda por bens de consumo e a dinâmica do crescimento. A maior parte da população mantinha-se submetida à lógica da subsistência e não tinha acesso aos frutos do progresso técnico. A precária inserção no mercado de trabalho e os baixos salários impediam sua incorporação ao mercado de consumo de massas. Num país de industrialização tardia, a estratégia de desenvolvimento deveria, necessariamente, priorizar a industrialização e a superação das heterogeneidades estruturais.

Em função da sua incipiente institucionalidade, a política social não foi contemplada como instrumento complementar para promover a redistribuição da renda e equidade social - ao contrário do que ocorria, simultaneamente, na Europa e nos EUA (1945-1975), onde houve articulação virtuosa entre os regimes de Estado de Bem-Estar Social e crescimento econômico.

De toda a forma, desde 1930 o Estado brasileiro cumpriu tarefas fundamentais num país de industrialização tardia. Os sobressaltos que se seguiram ao golpe de 1964 prosseguiram até os anos da década de 1980, com a crise do padrão de financiamento da economia e do setor público. Colocado no epicentro da crise, o Estado perdeu o comando da política macroeconômica e da iniciativa do crescimento.

7 Para o aprofundamento do pensamento da Cepal consultar os diversos artigos clássicos reunidos por Bielshowisky (2000). 
No plano internacional, o desenvolvimento capitalista baseado na Segunda Revolução Industrial sob a hegemonia americana, entrou em crise nos anos 70. O movimento de ajuste global dos países centrais criou ambiente favorável à ruptura dos compromissos entre o capital e o trabalho firmados nos "anos de ouro" (1945-1975) do capitalismo regulado. A ideologia neoliberal ganhou vigor e com o fim da bipolaridade mundial transformou-se no "pensamento único".

O Brasil foi um dos últimos países a ceder ao apelo neoliberal. Quando o fez, nos anos da década de 1990, adotou postura passiva, e nossos governos abriram mão das possibilidades de exercício de política macroeconômica ativa. $\mathrm{O}$ triunfo do neoliberalismo no contexto da globalizaçâo e sob a hegemonia das finanças internacionais ampliou o poder dos mercados e minou as bases do Estado brasileiro. Por mais de um quarto de século, a questão do desenvolvimento perdeu centralidade e os traços estruturais do subdesenvolvimento foram agravados. ${ }^{8}$

$\mathrm{Na}$ década passada, foram engendradas alternativas ao modelo econômico que vinha sendo implantado desde 1990 e que resultaram na melhoria dos padróes de vida da população. $\mathrm{O}$ crescimento teve consequências na impulsão do mercado de trabalho e do gasto social, potencializando os efeitos redistributivos da seguridade social instituída pela Constituição de 1988.

Com isso, após ter sido interditado por mais de duas décadas, o debate sobre o desenvolvimento voltou a mobilizar a reflexão acadêmica. Atualmente, esse pensamento está estruturado em duas correntes

8 Na visão de Cano (2010, p. 2), a um futuro estudioso da historiografia macroeconômica recente latino-americana não passará despercebida a drástica mudança qualitativa e quantitativa da formulação da política econômica a partir de fins da década de 1980. Desde então, "a maior parte dos economistas e acadêmicos abandonou suas preocupaçôes de longo prazo, de crescimento e desenvolvimento", ou seja, deixou de se preocupar com "o futuro do país”. Muitos "fizeram ainda pior" a partir da de 1990, ao declarar seu credo ao neoliberalismo. Nesse contexto, "de desenvolvimentistas de ontem, passaram a ser inimigos do elevado crescimento; de industrialistas, passaram a aceitar a reprimarização de nossa pauta exportadora. Trocaram a estratégia do protecionismo necessário, pela estultice da abertura internacional dos mercados de commodities, em troca de nosso imprescindível mercado interno de manufaturados". 
principais: o "novo desenvolvimentismo" e o "social-desenvolvimentismo” (BIANCARELLI, 2012).

No primeiro caso, o enfrentamento da questáo social aparece como objetivo desejável (BRESSER-PEREIRA; THEUER, 2012). No entanto, não são apontados caminhos para o atendimento desses anseios e a própria estratégia econômica limita essas possibilidades. Na visão crítica de Carneiro (2012, p. 772), "a omissão do papel do Estado como elemento crucial na redistribuição da renda é uma constante" no trabalho de muitos autores identificados com o novo desenvolvimentismo.

Esse ponto transparece, sobretudo, na distinção entre o investimento e o gasto corrente. $\mathrm{O}$ investimento teria importância maior para a sustentação do crescimento, e os autores desse matiz "esquecem-se de dar a ênfase necessária ao gasto corrente e às transferências e a seu papel crucial na redistribuição da renda e, portanto, à aceleraçáo do crescimento via ampliação do multiplicador", sublinha Carneiro.

A principal proposta sugerida na área fiscal é que "as receitas deveriam ser superiores aos gastos correntes mais os juros e a poupança daí resultante, suficiente para financiar o investimento". Como se sabe, parte expressiva do gasto social é classificada como despesas correntes.

Em contraposição ao novo desenvolvimentismo, a corrente social-desenvolvimentista busca articular um projeto mais homogêneo e de escopo mais amplo. A "ideia-chave" nas reflexóes envolvendo o social-desenvolvimentismo é a definição do "social como eixo do desenvolvimento”. Segundo Carneiro (2012, p. 774):

Propóe-se uma inversão de prioridades relativamente ao velho e ao novo desenvolvimentismo nos quais o desenvolvimento das forças produtivas era o principal objetivo a alcançar. A despeito de continuar relevante, esse objetivo estaria subordinado à meta de desenvolvimento social, vale dizer, a direção e intensidade do primeiro estariam subordinadas às prioridades do segundo. 
Mais especificamente, a ampliação do consumo de massas fundada na redistribuição da renda seria o fator dinâmico primordial do crescimento. Em função da relevância do mercado interno, o socialdesenvolvimentismo propôe "uma inversão radical nos determinantes do crescimento ao atribuir um papel chave ao consumo de massas e à redistribuição da renda”.

Esta estratégia teria de estar ancorada em políticas distributivas que acarretassem a melhoria progressiva da distribuição funcional da renda, ampliação dos rendimentos do trabalho acima da produtividade e ampliação do crédito. Essa combinação permitiria superar o caráter subordinado dos segmentos produtores de bens de consumo no capitalismo, afirma o autor.

Em trabalho recente, Bielschowsky (2012) sublinha que o país "tem o privilégio de possuir, ao mesmo tempo, três poderosas frentes de expansão". Primeiro, um amplo mercado interno de consumo de massa. Segundo, uma forte demanda nacional e mundial por seus abundantes recursos naturais. Terceiro, as perspectivas favoráveis quanto às demandas estatal e privada por investimentos em infraestrutura (econômica e social). Esses "três motores" do desenvolvimento seriam "um conjunto que poucos países do mundo possuem". Observe-se que dois "motores" estão vinculados às políticas sociais: mercado interno de consumo de massas e investimentos na infraestrutura social. Nesse sentido, a corrente "social-desenvolvimentista" fornece pistas importantes para ampliar a articulação entre as dimensões econômica e social do desenvolvimento.

Apesar da perspectiva promissora colocada pela corrente "social-desenvolvimentista", ainda existem lacunas na compreensão da complexidade da dimensão social do desenvolvimento. Em geral, como no passado, a ênfase continua recaindo na expansão do mercado interno de consumo de massas e na superação da persistente heterogeneidade estrutural. Por outro lado, questóes como concentração da riqueza (rural e urbana), injustiça tributária e desigualdades (regio- 
nais e entre classes sociais) no acesso aos bens e serviços sociais básicos (como saúde, educação, saneamento, transporte de massa, alimentação e previdência social) não têm merecido a mesma atenção do pensamento neoestruturalista.

Entende-se que o desenvolvimento no século 21 também requer açôes específicas voltadas para promover uma sociedade mais homogênea e igualitária. O projeto nacional também deve dispor de açóes específicas que promovam o bem-estar, distribuam a riqueza e incorporem as demandas derivadas das profundas transformaçóes que, em curto período, provocaram a rápida constituição de uma sociedade de massas, urbana e metropolitana.

Ao contrário do que ocorria em meados do século passado, a institucionalidade das políticas sociais brasileiras foi reforçada nas últimas décadas, em decorrência da Constituição de 1988. Serviços sociais básicos são considerados como direitos da cidadania e devem ser promovidos pelo Estado para o conjunto da população, incluindo os mais pobres.

Uma sociedade mais equânime e justa requer a universalização da cidadania e a desmercantilização das políticas sociais. Neste início do século 21 , não existem razóes para que deixemos, mais uma vez, de nos inspirar na experiência da socialdemocracia europeia do pós-guerra.

Em outras palavras, apesar dos avanços na institucionalidade das políticas sociais, o pensamento neoestruturalista continua a desconsiderar o seu papel como instrumento para promover a redistribuição da renda, a equidade social e a homogeneização do sistema econômico. Poucos analistas consideram, por exemplo, que a notável expansão da renda das famílias ocorrida na década passada, base do ciclo recente de crescimento, também foi determinada pelas transferências de renda da seguridade social (previdência rural e urbana, assistência social e seguro-desemprego), sobretudo devido aos impactos da valorização do salário mínimo sobre o piso dos benefícios. 
Em 2012, foram concedidos mais de 37 milhôes de benefícios (70\% equivalem ao piso do salário mínimo).

Mesmo assim, é preciso ressaltar que as postulações da corrente "social-desenvolvimentista" apontam um campo promissor de investigação em torno de temas que articulam as dimensóes social e econômica do desenvolvimento. ${ }^{9}$ Um obstáculo adicional deriva do fato de que, via de regra, esse debate não faz parte do horizonte dos especialistas em políticas sociais, cujos estudos são notoriamente marcados pelo recorte setorial.

\section{Condicionantes estruturais da dimensáo social do desenvolvimento: política, Estado e economia}

Uma das faces mais evidentes do conflito redistributivo reposto pelas marchas populares é a disputa pelos fundos públicos. ${ }^{10} \mathrm{O}$ atendimento das reivindicaçóes populares depende da capacidade da sociedade para apropriar-se dos recursos que têm sido capturados pelo poder econômico nos ganhos especulativos sobre a dívida pública e por inúmeros mecanismos de transferências tributárias. ${ }^{11}$

O enfrentamento desse conflito em favor das demandas da sociedade depende, em primeiro lugar, do reforço da esfera pública.

9 Consultar especialmente Carneiro (2012), Biancarelli (2012), Bielschowsky (2012) e Fonseca e Haines (2012).

10 Essa disputa ampliou-se a partir de 1990 com a adoção de política monetária baseada em juros básicos "obscenos" que elevou o endividamento e favoreceu a captura de recursos públicos pelo capital financeiro. A crescente transferência de renda para os detentores da riqueza (juros) permanece elevada. Em 2012, o Orçamento Geral da Uniāo (OGU) totalizou R \$ 1,4 trilhão. A parcela apropriada pelo capital financeiro (juros e encargos da dívida) representou $32 \%$ desse total (excluindo-se o refinanciamento da dívida). Os incentivos fiscais para a reproduçấo do capital também subtraem recursos do gasto social.

11 Analisando os protestos populares de 2013, o presidente do MST foi direto ao ponto: para atender os anseios da sociedade, afirma Stédile, o governo "precisa cortar juros e deslocar os recursos do superávit primário" que beneficia os rentistas para os investimentos produtivos e sociais. "E é isso que a luta de classes coloca para o governo Dilma: os recursos públicos irão para a burguesia rentista ou para resolver os problemas do povo?” (O significado e as perspectivas das mobilizaçōes de rua. Entrevista com João Pedro Stédile. Jornal Brasil de Fato, 24/6/2013). 
Sem o resgate da democracia e da política, as chances de êxito da agenda de desenvolvimento serão reduzidas. As manifestações populares reforçam a visão de que a sociedade demanda reforço da democracia participativa, prestação de contas pelos governantes e representantes, responsabilidade pública pela qualidade dos serviços, transparência no processo decisório e definição de prioridades que sejam do interesse geral e não do interesse particular (FLEURY, 2013).

Por outro lado, a crise do sistema partidário impóe limites ao presidencialismo de coalizão. As alianças para assegurar a governabilidade tornam qualquer governo refém de interesses fisiológicos e de partidos sem conteúdo programático ou com posições ideológicas antagônicas. Singer (2014) tem razão ao afirmar que "uma ampla camada de parlamentares fisiológicos chantageia o governo, obrigando-o a negociar no varejo, de modo ininterrupto. No meio dessas negociaçóes complicadas e inevitáveis, o interesse nacional vira mera moeda de troca”. Esse quadro limita as possibilidades de responder ao "desejo cada vez mais latente" por parte da sociedade de realização de um "conjunto de reformas estruturantes", conforme expressa recente resolução da Direçâo Nacional (PARTIDO DOS TRABALHADORES, 2014).

Nesse sentido, a reforma política é a mais importante delas. No debate em curso, diversos pontos têm sido discutidos, com destaque para o financiamento público exclusivo das campanhas, o voto distrital misto, a fidelidade partidária, o fim das coligaçóes proporcionais e a ampliaçáo da participaçáo direta da populaçáo na política. Na mesma perspectiva, se coloca o debate em torno da questão da democratização da mídia (FONTANA, 2013).

O segundo requisito para enfrentar o conflito redistributivo em favor das demandas da sociedade é o fortalecimento do papel do Estado. Será preciso libertá-lo das amarras impostas pelo mercado e recuperar sua capacidade de planejamento de longo prazo e de coordenação de políticas estruturais. 
Como se sabe, em sociedades de capitalismo tardio, o Estado cumpre tarefas essenciais no planejamento de açôes de longo prazo, financiamento dos projetos estruturantes e coordenação dos investimentos públicos e privados. À capacidade para promover uma política econômica adequada ao crescimento da economia, soma-se a necessidade de políticas setoriais específicas (industrial, inovação, tecnologia etc.) e outras que contribuam para a estruturação do mercado e das relaçôes de trabalho e para a distribuição de renda. Em uma sociedade desigual como a brasileira, cabe ao Estado arbitrar por projetos que incorporem as demandas dos segmentos sociais mais vulneráveis. Não obstante, esta tarefa também não é trivial. Após a experiência liberalizante dos anos da década de 1990, as bases materiais e financeiras do Estado foram minadas.

Como salienta Cano (2010, p. 7), "não há na história econômica do capitalismo, nenhum caso de país que tenha se desenvolvido sem o concurso expressivo de seu Estado nacional. E esse papel, no plano interno, cumpriu-se via indução, estímulos, incentivos fiscais, cambiais e financeiros, compras governamentais, pesquisa e desenvolvimento tecnológico etc. No plano externo, ele se traduz na defesa de sua moeda nacional, de sua força armada e sua diplomacia”. O papel do Estado nacional no desenvolvimento é inquestionável inclusive nos países do centro do sistema capitalista como Alemanha, Japão, Inglaterra e EUA. O mesmo se verifica nos casos da Coreia do Sul e de Taiwan, e mais recentemente a China, afirma o autor.

Finalmente, o crescimento econômico baseado na indústria e manufatura é condição necessária para o desenvolvimento. Como se sabe, o subdesenvolvimento constitui um processo histórico, criado a partir da forma como se dá a inserção na economia capitalista internacional. Nas últimas três décadas, tem havido regressão dos manufaturados na pauta exportadora, elevação dos déficits comerciais de produtos industriais de média a alta tecnologia e acentuada queda da participação da indústria de transformação no PIB (CANO, 2010). A questão 
que se coloca é se esse padrão de desenvolvimento é sustentável e viável no longo prazo, dado que a integração na economia mundial permanece dominada pela exportação de matérias-primas.

O recente ciclo de crescimento baseado, sobretudo, na expansão da renda das famílias e do crédito e nas exportaçóes de matérias-primas mostra sinais de esgotamento - em função do endividamento pessoal e do agravamento da crise financeira internacional, cuja natureza é complexa no contexto da globalização e da desregulamentação financeira.

Nesse cenário, o novo ciclo de crescimento da economia requer elevação da taxa de investimento situada em torno de 19\% do PIB entre os anos da década de 1970 e o início da década de 2000, a taxa de inversão caiu de $25 \%$ para $16 \%$ do PIB.

A questão do financiamento de longo prazo da infraestrutura e da indústria de maior complexidade tecnológica constitui outro ponto crítico, a despeito do papel que vem sendo desempenhado pelos bancos públicos. A reestruturação do sistema financeiro nacional para fortalecer o mercado de capitais e solucionar nosso estrutural estrangulamento do financiamento de longo prazo é outra tarefa que se impóe. ${ }^{12}$

O enfrentamento desses complexos problemas estruturais requer que a gestão macroeconômica e a estratégia de desenvolvimento estejam sintonizadas para criar ambiente favorável para os objetivos de mais longo prazo. No entanto, os pressupostos teóricos que dáo substrato ao tripé macroeconômico (câmbio flutuante, superávit fiscal e metas de inflação) "não convergem com o projeto social-desenvolvimentista”, afirmam Biancarelli e Rossi (2013). Esse modelo foi concebido para "impor limites à discricionariedade da atuação do Estado e submeter as autoridades políticas aos princípios de uma visão liberal de desenvolvimento", sublinham os autores.

12 Para o aprofundamento desses pontos, consultar Cano (2010). 
Na visão de Barbosa (2014), com o aprofundamento da crise financeira dos países desenvolvidos, que alterou o padrão de inserção externa da economia brasileira, o tripé transformou-se numa "armadilha para o crescimento". Em suas palavras:

O déficit em transaçôes correntes se amplia num contexto de baixo crescimento e pressóes inflacionárias concentradas no setor de serviços. O governo faz o câmbio se valorizar - por meio do aumento dos juros - para controlar uma inflação que não é de demanda, penalizando os investimentos públicos e as políticas sociais a fim de assegurar o superávit primário. Paralelamente, as altas taxas de juros impóem um patamar de rentabilidade mínimo para as empresas concessionárias de serviços públicos, comprometendo o papel do Estado na definição de metas de investimento e de preços exequíveis para o sistema econômico. Os juros altos impóem ainda uma pressão de custos para o sistema produtivo, travando a ampliação do mercado de capitais e jogando para o BNDES a hercúlea tarefa de atuar em todas as frentes - infraestrutura, inovação, setor industrial, governos municipais e estaduais e internacionalização das empresas brasileiras. Para completar, constrangem a expansão dos gastos em educação, saúde, habitação e mobilidade urbana, que precisam de mais investimentos e cujos impactos sobre o emprego e a renda se mostram expressivos. Para que as engrenagens deste capitalismo voltem a funcionar (...) temos que superar o tripé da política econômica (...).

Não obstante, ficamos presos ao tripé, "reverenciado como se fosse a própria santíssima trindade", afirma o autor.

A promoção dessas mudanças estruturais é de difícil encaminhamento no curto prazo, pois significa caminhar no contrafluxo da ideologia dominante e da correlação de forças favorável ao poder econômico.

Observe-se que, inicialmente, o governo Dilma Rousseff procurou alterar a gestão ortodoxa do tripé macroeconômico. Entretanto, a 
reação dos mercados forçou o governo a recuar. Mesmo assim, o "terrorismo econômico" continua em marcha.

O dilema de qualquer governo é arbitrar entre a pressão das ruas e as pressóes dos mercados. No auge das manifestaçóes populares, a presidenta da República sintetizou esse conflito ao afirmar que a sociedade estaria exigindo que "o cidadão, e não o poder econômico, esteja em primeiro lugar”. Posteriormente, diante das pressóes do mercado, procurou conciliar o inconciliável. De um lado, foram apresentadas propostas de pactos para enfrentar as demandas populares: Pactos da Educação Nacional, Mobilidade Urbana e Saúde Pública. De outro, foi lançado o Pacto pela Responsabilidade Fiscal, exigido pelo poder econômico. Essas tensões ficaram mais evidentes com as sucessivas elevaçôes da taxa básica de juros realizada pelo Banco Central desde o início de 2013 (de 7,5\% para 11,0\%).

Por essas razões, fica evidente que, sem pressão social, não será possível fazer com que "os interesses do cidadão venham em primeiro lugar".

\section{Eixos sobre a dimensáo social do desenvolvimento: propostas para o debate ${ }^{13}$}

Um projeto de desenvolvimento para o Brasil do século 21 continua a depender de mudanças estruturais nos rumos da política e da economia. Mas ele não pode prescindir de objetivos voltados para combater as desigualdades da renda, da riqueza, da estrutura

13 As notas a seguir baseiam-se em duas frentes de pesquisas coordenadas pelo autor em 2013. A primeira, no âmbito do projeto "Desafios e oportunidades do desenvolvimento brasileiro: dimensôes econômicas e sociais” promovido pelo Centro de Gestâo de Estudos Estratégicos (CGEE) e realizado em articulação com o Instituto de Economia da Unicamp, por meio da Rede Desenvolvimentista (Aspectos Econômicos) e pela rede Plataforma Política Social (Aspectos Sociais). Esses eventos foram organizados de forma articulada com o intuito de integrar o debate entre as dimensôes econômicas e sociais do desenvolvimento. A reflexão sobre a dimensão social foi organizada em torno de 12 temáticas e reuniu 51 especialistas (consultar CGEE, 2013). O segundo campo de reflexão foi coordenado em conjunto com a especialista Ana Maria Medeiros da Fonseca e realizado no âmbito do projeto "Propostas para o Brasil” realizado pela Fundação Perseu Abramo. Os resultados estão consolidados em 22 artigos, escritos por 41 especialistas (consultar FAGNANI; FONSECA, 2013, a e b). 
tributária, do mercado de trabalho e do acesso aos bens e serviços sociais básicos. Portanto, de forma sucinta, este ensaio propóe para o debate os seguintes pontos de uma agenda sobre a dimensão social do desenvolvimento:

- Desigualdades de renda e de riqueza.

- Desigualdades da estrutura de imposto.

- Desigualdades do mercado de trabalho.

- Desigualdades de acesso aos serviços sociais: o desafio de universalizar a cidadania.

- As reformas para ampliar a cidadania social.

- O pós-Bolsa Família: o desafio de transformar os brasileiros pobres em cidadãos portadores de direitos da cidadania.

- Os novos desafios colocados pela transição demográfica.

\section{Desigualdades de renda e de riqueza}

O primeiro núcleo estruturante da dimensão social do desenvolvimento deve ser o combate às desigualdades de renda e de riqueza.

Entre 2001 e 2011, o índice de Gini caiu de 0,594 para 0,527. A concentração da renda recuou aos padrôes de 1960, mas ainda permanece entre as mais elevadas do mundo. $\mathrm{Na}$ década passada, saímos da $3^{\mathrm{a}}$ para a $15^{\mathrm{a}}$ pior posição global e ainda estamos distantes de países mais igualitários onde o Gini é inferior a 0,4. Paralelamente aos desníveis regionais, existem as extremas desigualdades de oportunidades entre os vários grupos sociais (BARBOSA; AMORIM, 2013).

Temos ainda vivo, no Brasil, o problema da reforma agrária. Esse tema deixou de ser 'questão' para os países centrais, já que essas naçôes fizeram a reforma agrária em nome da modernização do capitalismo. O Brasil, ao contrário, teve vários ensaios abortados e, aqui, o tema permanece atual, ao contrário do que prega a voga liberal dominante. A secular concentração da riqueza agrária no Brasil permanece intocada: "em torno de $1 \%$ dos proprietários fundiários 
controlam metade de todas as terras" (STÉDILE, 2014). Por essa razão, "a reforma agrária está na ordem do dia como necessidade para construirmos uma sociedade democrática e ter o desenvolvimento social", afirma o presidente do Movimento dos Trabalhadores Sem Terra (MST). Não obstante, o avanço do agronegócio convive com uma nova etapa de esvaziamento da reforma agrária (ROMAMO; CAMPOLINA; MENEZES, 2013).

As desigualdades da sociedade brasileira também se refletem na apropriação física do espaço urbano. A reforma urbana continua sendo urgente e necessária para impedir o avanço da especulação e das formas predatórias de uso e de ocupação do espaço das cidades. Os recentes avanços na inclusão social e na distribuição da renda são insuficientes para termos "uma cidade mais justa", afirma Maricato (2013). Para ela, "não basta distribuir renda"; também é preciso "distribuir cidade".

\section{Desigualdades da estrutura de impostos}

Combater as desigualdades sociais também requer ações no sentido de se enfrentarem as injustiças do sistema de impostos, cujos núcleos centrais vigoram desde meados da década de 1960.

Estudo realizado por Lavinas (2013) aponta que, na literatura sobre finanças públicas, consolidou-se o entendimento de que a tributação direta (que incide sobre a renda e o patrimônio) tende a ser progressiva. Nos países-membros da OCDE, o peso desses tributos representa 33\% da arrecadação total. No Brasil, ao contrário, os tributos que incidem sobre a renda (pessoa física e jurídica) corresponderam $19,0 \%$ da arrecadação total em 2011; e aqueles que taxam o patrimônio equivaliam apenas a $3,7 \%$. Por sua vez, os tributos indiretos (incidentes sobre consumo) representaram $49,2 \%$ da arrecadação total. A carga tributária indireta atinge proporcionalmente os mais pobres.

Estudos consolidados por Afonso (2013) apontam que as pessoas que recebiam até dois salários mínimos comprometiam 53,9\% da sua renda com o pagamento da carga tributária indireta em 2008. Em 
contrapartida, aqueles que percebiam mais de trinta salários mínimos comprometiam 29,0\% da renda com impostos indiretos.

Mais grave é o fato de que a reforma tributária que tramita no Congresso Nacional não caminha na direção de corrigir essa injustiça crônica. Muitos estudiosos chamam a atenção para a ausência de compromisso com a justiça tributária (KHAIR, 2008; SALVADOR, 2008; POCHMMAN, 2008).

Além disso, a proposta embute ameaças de desmonte das bases de financiamento das políticas sociais conquistadas pela Constituição de 1988. Observe-se que, por detrás da simplificação, esconde-se o fim das vinculações, a desoneração da folha de contribuição dos empregadores para previdência social e a extinção de fontes de financiamento do orçamento da seguridade social (Cofins, PIS, Contribuição Social do Salário-Educação e CSLL).

A concretização dessas mudanças - sem a garantia constitucional de vinculação de recursos - fragilizará o financiamento da educação e o orçamento da seguridade social, afetando a sustentação dos gastos em setores como previdência social (INSS urbano e previdência rural), assistência social, saúde, seguro-desemprego, geração de emprego e capacitação profissional (Fundo de Amparo ao Trabalhador, FAT) (FAGNANI, 2008).

\section{Desigualdades do mercado de trabalho}

Na última década, ocorreram avanços na geração de empregos com carteira assinada, redução do desemprego, valorização da renda do trabalho e redução da informalidade.

Mesmo assim, a estrutura produtiva e do mercado de trabalho ainda guarda traços e características de economias subdesenvolvidas ou periféricas: elevada heterogeneidade, presença disseminada do subemprego, excedente estrutural de mão de obra, alta concentração da renda, 
baixos salários e elevada rotatividade dos postos de trabalho (OLIVEIRA, 2013; IBARRA, 2013).

Continuam a existir desigualdades na distribuição da renda do trabalho e insegurança para os trabalhadores que estão submetidos aos “contratos flexíveis” (KREIN, 2003).

A ampliação da participação relativa do emprego industrial em segmentos de maior valor agregado, inovação e tecnologia, o fortalecimento da ação sindical e a ampliação do papel do Estado na regulação e na fiscalização das relaçôes trabalhistas também são desafios a serem enfrentados.

O enfrentamento desses pontos conflita com a atual etapa da concorrência capitalista, marcada pela maior mobilidade e concentração do capital. As estratégias de localização espacial das corporaçôes internacionais impóem a liberalização do comércio, o controle da difusão do progresso técnico e o enfraquecimento da capacidade de negociação dos trabalhadores. ${ }^{14}$

\section{Desigualdades de acesso aos serviços sociais: o desafio de universalizar a cidadania}

Outro núcleo estruturante da dimensão social do desenvolvimento deve ser o combate às desigualdades de acesso aos bens e serviços sociais básicos.

A Constituição da República consagrou as bases de um sistema de proteção inspirado nos princípios da universalidade, da seguridade e da cidadania. A Constituição zela pela igualdade de direitos, mas, na prática, há uma considerável distância entre direitos estabelecidos e o exercício desses direitos. As políticas sociais universais foram mercantilizadas e apresentam lacunas e vazios de oferta de serviços que se refle-

14 Luiz G. Belluzzo. Mobilidade do capital e progresso técnico. Valor, 05/03/2013. 
tem na falta de acesso ou acesso desigual para as diversas camadas da população. O desafio que se impõe é universalizar a cidadania, equalizando-se as condiçóes de acesso para todos, incluindo os segmentos pobres e vulneráveis, bem como a "desmercantilização" da oferta de serviços (LAVINAS, 2013).

Qualquer agenda de desenvolvimento inclui a educação como um de seus componentes. Apesar dos avanços recentes, o país ainda se encontra distante de um ideal de igualdade de oportunidades educacionais. A educação acumula desigualdades e ausências; a escolaridade média da população é baixa em relação aos parâmetros internacionais; o analfabetismo de jovens e adultos permanece elevado; a universalização da oferta ainda apresenta lacunas no ensino infantil, médio e superior; e estar na escola não garante o aprendizado, e a questão da qualidade permanece viva (ROCHA, 2013; WALTENBERG, 2013).

Consolidar a seguridade social de acordo com os princípios estabelecidos pela Constituição da República é outra tarefa que se impóe. Desde a promulgação da Carta de 1988, a seguridade social tem enfrentado forte oposição de setores da sociedade e do mercado. Esse fato contribuiu para que princípios constitucionais da organização da seguridade social, do orçamento da seguridade social e do controle social (Conselho Nacional da Seguridade Social) fossem descumpridos. Nesta perspectiva, será preciso organizar a seguridade social e o orçamento da seguridade social como reza a Carta de 1988. Também será preciso instituir o Conselho Nacional da Seguridade Social, previsto no parágrafo único do art. 194 da Constituição Federal.

A consolidação da seguridade social também requer a extinção da Desvinculação das Receitas da União (DRU) e a revisão da política de desoneração fiscal que, em conjunto, subtraem parcelas expressivas de recursos que poderiam ser aplicados nos setores da saúde, previdência, assistência e seguro-desemprego (FAGNANI; TONELLI VAZ, 2013a). 
Observe-se que, em 2012, a DRU retirou da seguridade social R $\$$ 52,6 bilhóes. O acumulado, apenas para o período 2005-2012, totaliza mais de $\mathrm{R} \$ 286$ bilhóes. Essa subtração de recursos, que restringe o superávit do setor, não aparece nos relatórios oficiais como uma transferência de recursos da seguridade social para o orçamento fiscal. É como se esses recursos fossem, por natureza, do orçamento fiscal.

Ainda em 2012, as isenções tributárias concedidas sobre as fontes da seguridade social (CSLL, PIS/Pasep, Cofins e Folha de Pagamento) totalizaram R $\$ 77$ bilhões (1,7\% do PIB). A previsão para 2014 é que elas atinjam $\mathrm{R} \$ 123,2$ bilhóes (2,7\% do PIB) (Anfip, 2013). Assim como a DRU, esse processo também deprime o superávit da seguridade social e poderá comprometer sua sustentação financeira no futuro.

$\mathrm{Na}$ previdência social, será preciso enfrentar o debate sobre o mito do "déficit". Essa falácia, sem amparo constitucional, não considera a previdência como parte da seguridade social. Assim, desconsidera as demais receitas que compóem o orçamento da seguridade social. Paradoxalmente, essa contabilizaçáo tem sido reproduzida pelo Ministério da Previdência Social, desde 1989.

A preservação das fontes de financiamento da previdência social também requer a alteração da forma oficial de contabilização das renúncias previdenciárias, que não considera as renúncias fiscais como receitas do setor. Da mesma forma, requer o fim da Desvinculação das Receitas da União (DRU), criada em 1994 e renovada continuamente. Outro desafio é extinguir o Fator Previdenciário e o teto nominal reduzido para os valores da aposentaria, forçando a adesão dos segurados ao sistema privado suplementar (FAGNANI; TONELLI VAZ, 2013b).

Outro desafio é ampliar a cobertura previdenciária. Na década passada, a expansão da cobertura dos trabalhadores ativos reverteu quadro crítico vivido desde 1992. Em 2010, pôde-se recuperar o patamar de 18 anos atrás. Mesmo assim, mais de um terço dos trabalhadores brasileiros não contribuem para a previdência social, ou seja, não 
estão protegidos no presente e não terão proteção na velhice (COSTANZI; ANSILIERO, 2013).

No caso da saúde, a Constituição da República consagrou o Sistema Único de Saúde (SUS) como público, universal e baseado na cooperação entre entes federativos. Mas, desde os anos 1990, o Parlamento e os três entes federativos do Poder Executivo não priorizaram investimentos na ampliação da oferta pública de serviços, especialmente, nos sistemas de média e alta complexidade. Diversos segmentos da população não têm acesso adequado sequer aos serviços de atenção básica. O SUS surgiu como antítese da política privatista adotada pela ditadura militar, mas a democracia brasileira não foi capaz de barrar a mercantilização do setor (VIANA; SILVA; LIMA; MACHADO, 2013).

Com relação ao serviço social, os avanços ocorridos na instituição do Sistema Único de Assistência Social (Suas) precisam ser consolidados. Existe amplo espaço de reformas para articular a assistência social com os demais setores que compóem a seguridade social. Os desafios para o futuro também envolvem a superação da tradição conservadora e patrimonialista que ainda prevalece no setor. Outro desafio é avançar nas dimensóes que transcendem os benefícios monetários (Bolsa-Família e Benefício de Prestação Continuada). Nesse sentido, a consolidação do Suas também depende do fortalecimento da oferta de serviços socioassistenciais, o que requer a efetiva responsabilização dos três entes federativos na produção da atenção e no seu financiamento (SPOSATI; CORTES; COELHO, 2013).

O programa Seguro-Desemprego apresenta uma anomalia específica do mercado de trabalho brasileiro: a demanda por seguro-desemprego aumenta quando a taxa de desemprego cai. Esse paradoxo é explicado, especialmente, pela elevada taxa de rotatividade do emprego (CARDOSO JR.; MUSSE, 2013). 
Além disso, o Sistema Público de Emprego beneficia os trabalhadores mais bem inseridos no mercado laboral, mas ele não é eficaz na inclusão produtiva, num cenário em que mais de dois terços dos adultos beneficiários do programa Bolsa-Família trabalham em empregos precários (IBARRA, 2013).

Com relação à alimentação, o acesso aos alimentos foi impulsionado, na última década, em decorrência de muitos fatores: a melhoria da renda das famílias pobres, a inserção do direito à alimentaçâo entre os direitos sociais; a intensa atividade do Conselho Nacional de Segurança Alimentar e Nutricional (Consea); da instituição do Sistema Único de Segurança Alimentar e Nutricional (Susan); do impacto do Programa Nacional da Agricultura Familiar (Pronaf); do Programa de Aquisição de Alimentos da Agricultura Familiar (PAA) e do Programa Nacional de Alimentação Escolar (PNAE). Todavia, a implantação do Susan é recente (2005) e sua consolidação ainda enfrenta muitos obstáculos (MENEZES; CAMPOLINA; ROMANO, 2013).

A agenda de desenvolvimento também deve levar em conta que, nos últimos 60 anos, o Brasil nunca contou com políticas nacionais de habitação popular, saneamento e mobilidade urbana que fossem portadoras de recursos financeiros e institucionais compatíveis com os problemas estruturais agravados desde meados do século passado em função da acelerada urbanização. Como consequência, as políticas habitacionais durante muitos anos foram inacessíveis para as camadas de baixa renda (ELOY; COSTA; ROSSETTO, 2013). No saneamento ambiental, mais de $40 \%$ dos brasileiros não têm acesso adequado à água, e mais de $60 \%$ não têm coleta de esgoto adequada (HELLER, 2013). O atual caos do transporte revela um quadro crônico da precária mobilidade urbana com a insuficiência da oferta de transporte de massa (FAGNANI, 2011).

As desigualdades raciais e de gênero também estão enraizadas na sociedade. $\mathrm{O}$ total de estudantes brancos de 18 a 24 anos que frequentam o ensino superior é quase o dobro dos jovens estudantes pretos ou 
pardos. No mercado de trabalho, a proporção de pretos ou pardos em trabalhos informais é bem superior à população de cor branca. A taxa de mortalidade por agressões na população jovem negra é quase três vezes superior à que se constata na população branca. Além disso, entre os 10\% mais pobres da populaçáo brasileira, mais de dois terços são pretos ou pardos (IBGE, 2013)..$^{15}$

\section{As reformas para ampliar a cidadania social}

Outro núcleo estruturante da dimensão social do desenvolvimento deve ser a realização de reformas estruturais necessárias para promover a universalização da cidadania social.

O financiamento das políticas sociais universais requer reforma tributária que promova a justiça fiscal, taxando-se o lucro e o patrimônio, e não o consumo. Como mencionado, o projeto que tramita no Congresso Nacional não caminha nesta direção e, mais grave, extingue as fontes de financiamento constitucionalmente vinculadas aos gastos sociais universais.

Além disso, é preciso restabelecer os mecanismos de financiamento que foram assegurados pela Constituição da República, mas desfigurados pela área econômica na década de 1990. A DRU e a captura de recursos do orçamento da seguridade social são exemplares. Outro ponto diz respeito à política de desoneração de impostos, implantada desde meados da década passada, que limita as bases de financiamento da proteção social.

Da mesma forma, será preciso restabelecer o pacto federativo, esvaziado pela crescente centralização das receitas tributárias na esfera federal, bem como pela elevação do endividamento de estados e municípios em função da política monetária restritiva, seguida pela adoção de severo programa de ajuste fiscal para esses entes que foi adotado nos

15 Consultar: <http://biblioteca.ibge.gov.br/visualizacao/livros/liv66777.pdf>. 
anos da década de 1990. Esse fato limita a gestão pública dos serviços sociais que, de forma correta, passaram a ser administrados pelos municípios em cooperação com os demais entes federativos.

A superação das desigualdades do acesso aos bens e serviços sociais também requer que se enfrentem os processos de mercantilização que foram difundidos a partir de 1990 pelos três níveis de governo para diversos setores, com destaque para a saúde, o saneamento, o transporte público, a assistência social, a previdência e a educação.

Assegurar serviços públicos de qualidade a todos os brasileiros também exige o fortalecimento da gestão estatal, enfraquecida pelo avanço de diversos mecanismos de gestão privada que cria duplicidades, fragmentação e dificuldades para assegurar um padrão de eficiência. Dentre diversos mecanismos que limitam a gestão estatal eficiente, destaca-se a Lei de Responsabilidade Fiscal que simultaneamente restringe a contratação de pessoal e incentiva a difusão de organizaçóes sociais, ONGs, Oscips e cooperativas. Essas organizaçóes sociais (criadas em 1997) acabam sendo utilizadas com a finalidade de "burlar" a Lei de Responsabilidade Fiscal (criada em 1999), pois os gastos dessas instituiçóes são contabilizados como "serviços de terceiros" e não como “despesas de pessoal”.

\section{O "pós-Bolsa-Família": o desafio de transformar os brasileiros pobres em cidadáos portadores de direitos da cidadania}

Outro eixo estruturante da dimensão social do desenvolvimento deve ser enfrentar o desafio de transformar os brasileiros pobres em cidadãos portadores de direitos da cidadania.

O programa Bolsa-Família é peça importante do amplo sistema de proteção social brasileiro e cumpre papel de relevo no combate às situaçóes de vulnerabilidade extrema, tendo contribuído para que a porcentagem de pessoas que vivem em pobreza extrema caísse pela metade entre 2003 e 2011. 
O desafio é consolidar os progressos recentes e, especialmente, avançar na difícil perspectiva de transformar todos os brasileiros em cidadãos plenos. Em parte, esse difícil caminho vem sendo trilhado pelo Plano Brasil Sem Miséria, mas os problemas ainda são complexos.

A questão posta para o futuro é intensificar as articulações do programa Bolsa-Família e do Plano Brasil Sem Miséria com as políticas sociais universais introduzidas pela Constituição de 1988. Isso requer andar por via de mão dupla. De um lado, exige esforços dos ministérios setoriais responsáveis pela gestão das políticas universais, no sentido de ampliar a oferta de serviços para as regióes e populaçóes não atendidas. Isso não significa "focalizar" as políticas universais, mas, sim, expandir essas políticas para que elas também atendam os contingentes mais pobres. E, de outro lado, exige esforços do Ministério do Desenvolvimento Social no sentido de ampliar serviços e buscar articulaçóes institucionais com os demais órgãos sociais e com os entes da Federação (FONSECA; JACCOUD; KARAM, 2013; JACCOUD, 2013).

\section{Os novos desafios colocados pela transição demográfica}

Finalmente, o último núcleo estruturante da dimensão social do desenvolvimento deve ser enfrentar o fato de que, além desses "velhos problemas", a dinâmica demográfica pressionará o Estado, a sociedade e a democracia para que enfrentem novos desafios (RIBEIRO DE OLIVEIRA, 2013).

O envelhecimento da população aumentará os gastos públicos com saúde e previdência. De fato, entre 2000 e 2050 a população de idosos aumentará (de 5,5\% para 15,3\% da população total). Todavia, não existe nenhuma "bomba" que precise ser desarmada agora para evitar a "catástrofe". Em parte porque a reforma da previdência realizada em 1998 (EC 20) já tornou as regras de acesso mais rigorosas que as vigentes na maior parte dos países desenvolvidos (FAGNANI, 2007). 
Por outro lado, a população de até 14 anos cairá (de 29,8\% para 19,3\%). Logo, a pressão por gastos com idosos será contrabalançada pela menor pressáo do gasto com educação. Hoje, temos cerca de 46 milhôes de jovens em idade escolar. Em 2040, serão cerca de 20 milhôes.

Mais importante: o percentual de pessoas em idade ativa (15 a 64 anos) aumentará e abrirá uma "janela de oportunidade demográfica”. O desempenho da economia poderá (ou não) criar condições para a incorporação desse contingente crescente em idade ativa; poderá (ou não) apresentar condiçóes materiais para que essa enorme "janela de oportunidades" seja aproveitada.

Portanto, não está dado que transição demográfica será um ônus inevitável. Ela poderá ser "ônus" ou "bônus" - dependerá das opçóes econômicas que serão adotadas. Se formos capazes de adotar um modelo de desenvolvimento que assegure emprego e renda e avance na redução das desigualdades e na melhoria da distribuição da renda, em 2050 seremos uma sociedade menos vulnerável, com maior preparo educacional e qualificação profissional e menos dependente dos programas de proteçấo social. Uma sociedade na qual os indivíduos terão maior capacidade de enfrentar com autonomia suas demandas e necessidades nos diversos ciclos da vida (incluída a proteçáo na velhice).

Além disso, plantamos as bases de uma proteção financeira para o futuro. Caso necessário, em 2050, parte da capitalização do Fundo Soberano, que está sendo constituído com recursos das taxas e royalties da exploração do pré-sal, poderá ser canalizada para o financiamento da previdência, seguindo-se a exemplar experiência da Noruega que inspirou a criação do fundo brasileiro.

Contudo, as forças do mercado enveredam pela trilha do terrorismo demográfico: difundem a questionável visão de que a "bomba demográfica" levará, inevitavelmente, à "catástrofe" fiscal. O objetivo oculto é impulsionar novas rodadas de supressão de direitos sociais. 
Nesse sentido, a questão que se coloca é: Como enfrentar esse desafio na perspectiva progressista? Como financiar a saúde e a previdência num contexto de queda da relação entre contribuintes e beneficiários? Como capturar parcela da renda auferida pelos ganhos de produtividade?

\section{Notas finais}

Neste ensaio, argumentamos que o papel da democracia na representação dos interesses da sociedade foi mitigado após quatro décadas de dominância do capital financeiro e de hegemonia da doutrina neoliberal.

Uma das consequências disso tem sido a fragmentação da luta política em torno de temas setoriais específicos. Com raras exceçôes, perdeu-se a visão de que não será viável encaminhar muitas dessas pautas se não se enfrentarem questóes estruturais mais amplas tratadas na perspectiva do desenvolvimento.

Os protestos populares iniciados em 2013 parecem abrir perspectivas mais promissoras para impulsionar a retomada do pensamento crítico sobre o desenvolvimento. O pano de fundo mais profundo desses protestos é dado pela crônica desigualdade social brasileira. Se essa hipótese estiver correta, os protestos repuseram o conflito redistributivo entre capital e trabalho no centro do debate nacional.

As respostas exigem mudanças estruturais pensadas na perspectiva de um projeto nacional de transformação. Procurando contribuir para esse debate, foram apresentados pontos que poderão ser contemplados numa agenda sobre a dimensão social do desenvolvimento.

Muitas opções adotadas no passado não têm mais validade e será preciso desbravar caminhos inovadores para enfrentar os desafios associados à falência do modelo global de acumulação. É necessário questionar o modelo civilizatório e as bases do desenvolvimento capitalista 
que chegou ao seu limite e não tem mostrado condiçôes de incorporar países e populaçóes.

Outro desafio é conciliar desenvolvimento com a sustentabilidade ambiental. Como aponta Grzybowski (2011), "não dá para salvar o planeta e esquecer a humanidade". A questão que se coloca é "como mudar, conciliando a agenda da sustentabilidade da natureza e da vida com a justiça social"?

Mesmo com dúvidas e incertezas, cabe ao campo progressista ampliar os diálogos na perspectiva de se construírem consensos em torno de um projeto identificado com as reivindicaçóes da sociedade. A tarefa é complexa, tanto pelo caráter estrutural dos fenômenos quanto pelo conservadorismo das elites, num contexto em que a correlação de forças favorece as finanças globalizadas. Todavia, não há outro caminho a seguir, caso os setores progressistas queiram, de fato, enfrentar o mal-estar contemporâneo exposto pelas ruas.

Para não haver um personagem à procura de autor, fica a pergunta: quem serão os personagens-atores que liderarão este processo de articular as demandas da sociedade, na perspectiva da transformação social?

\section{Referências}

AFONSO, J. R. Apresentação PTT - Estatísticas recentes sobre carga tributária, 2011, arquivo eletrônico. Informe JRRA (informe@ joserobertoafonso.com.br). 2013.

ALTMAN, B. As ruas fazem soar alarme para o PT e o governo, Brasil 247. 19/07/2013.

ANFIP. Associação Nacional dos Auditores Fiscais da Receita Federal do Brasil. Análise da seguridade social 2012. Brasília: Anfip e Fundação Anfip de Estudos da Seguridade Social, 2013, 131 p.

BARBOSA, A. F. O Brasil precisa romper camisa de força e superar tripé da estagnação. Valor Econômico, 13/6/2014. Disponível em: <http://www. revistaforum.com.br/rodrigovianna/forca-da-grana/brasil-precisa-rompercamisa-de-forca-e-superar-tripe-da-estagnacao/> . 
BARBOSA, A. F.; AMORIM, R. L. Desafios para o enfrentamento da desigualdade no Brasil. In: FAGNANI, E.; FONSECA, A. (Orgs.) Politicas sociais, universalização da cidadania e desenvolvimento: economia, distribuição da renda, e mercado de trabalho. São Paulo: Fundação Perseu Abramo, 2013a.

BELLUZZO, L. G. Condenados à liberdade. Carta capital, 24/6/2013. $2013 \mathrm{a}$.

. Entrevista. Carta Capital resumida e publicada no Portal Carta Maior com o título Com os dogmas neoliberais não se constrói uma nação e o seu desenvolvimento, 17/7/2013. 2013b.

BIANCARELLI, A. Economia, Sociedade e Desenvolvimento, 20 anos: notas de apresentação. Economia e Sociedade, v. 21, Número Especial, dez./2012.

BIANCARELLI, A.; ROSSI, P. A política macroeconômica em uma estratégia social-desenvolvimentista. In: FAGNANI, E.; FONSECA, A. (Orgs.) Políticas sociais, universalizaçâo da cidadania e desenvolvimento: economia, distribuição da renda, e mercado de trabalho. São Paulo: Fundação Perseu Abramo, 2013a.

BIELSCHOWSKY, R. Estratégia de desenvolvimento e as três frentes de expansão no Brasil: um desenho conceitual. Economia e Sociedade, v. 21, Número Especial, dez./2012.

Record, 2000.

. (Org.) Cinquenta anos de pensamento da Cepal. Rio de Janeiro:

BRESSER-PEREIRA, L. C.; THEUER, D. Um Estado novodesenvolvimentista na América Latina? Economia e Sociedade, v. 21, Número Especial, dez./2012.

CANO, W. Uma agenda nacional para o desenvolvimento. Texto submetido à publicação em Tempo do Mundo, do Ipea, em 15/07/2010.

CARDOSO DE MELLO, J. M. O capitalismo tardio; contribuição à revisão crítica da formação e do desenvolvimento da economia brasileira. 30 Anos de Economia, n. 4. Campinas: IE-Unicamp, 1998.

CARDOSO JR., J. C.; MUSSE, J. S. Seguridade social, trabalho e políticas de emprego no Brasil: questôes e soluçôes para ampliar a efetividade do seguro-desemprego e do Fundo de Amparo ao Trabalhador. In: FAGNANI, E.; FONSECA, A. (Orgs.) Políticas sociais, universalização da cidadania e desenvolvimento: economia, distribuição da renda e mercado de trabalho. Sáo Paulo: Fundação Perseu Abramo, 2013a. 
CARNEIRO, R. Velhos e novos desenvolvimentismos. Economia e Sociedade, v. 21, Número Especial, dez./2012.

CARVALHO, J. M. Cidadania no Brasil: o longo caminho. Rio de Janeiro: Civilização Brasileira, 2001.

CGEE. Centro de Gestão de Estudos Estratégicos. Desafios ao desenvolvimento brasileiro: uma abordagem social-desenvolvimentista. Brasília: CGEE, 2013. 136p.

COSTANZI, R. N.; ANSILIERO, G. Inclusão previdenciária e mercado de trabalho. In: FAGNANI, E.; FONSECA, A. (Orgs.) Politicas sociais, universalização da cidadania e desenvolvimento: educação, seguridade social, infraestrutura urbana, pobreza e transição demográfica. São Paulo: Fundação Perseu Abramo, 2013b.

DRAIBE, S. M. As políticas sociais e o neoliberalismo: reflexões suscitadas pelas experiências latino-americanas. Revista da USP, n. 17.

DREYFUSS, René Armand. 1964. A conquista do Estado: ação política, poder e golpe de classe. Petrópolis: Vozes, 1981.

ELOY, C. M.; COSTA, F; ROSSETTO, R. Direito à moradia no Brasil: a política de subsídios habitacionais. In: FAGNANI, E.; FONSECA, A. (Orgs.) Políticas sociais, universalização da cidadania e desenvolvimento: educação, seguridade social, infraestrutura urbana, pobreza e transição demográfica. São Paulo: Fundação Perseu Abramo, 2013 b.

FAGNANI, E. Tributação, equidade e financiamento da Política Social. Nota Introdutória. Carta Social e do Trabalho, n. 8, jan.-ago./2008, p. 1-5. . Política social no Brasil (1964-2002): entre a cidadania e a caridade.

Tese de Doutorado. Campinas: IE-Unicamp, 2005. . Previdência social e desenvolvimento econômico. Artigo apresentado no seminário Desafios para a previdência social no Brasil, organizado pelo Instituto de Pesquisas Econômicas Aplicadas (Ipea) e pela Embaixada Britânica, Brasília, 6-7/12/2007. . Fora dos trilhos. Folha de S.Paulo, 08/09/2011.

FAGNANI, E.; TONELLI VAZ, F. Previdência e seguridade social: velhos mitos e novos desafios. In: FAGNANI, E.; FONSECA, A. (Orgs.) Politicas sociais, universalização da cidadania e desenvolvimento: educação, seguridade social, infraestrutura urbana, pobreza e transição demográfica. São Paulo: Fundação Perseu Abramo, 2013b. 
. Seguridade social, direitos constitucionais e desenvolvimento. In: FAGNANI, E.; FONSECA, A. (Orgs.) Políticas sociais, universalização da cidadania e desenvolvimento: educação, seguridade social, infraestrutura urbana, pobreza e transição demográfica. São Paulo: Fundação Perseu Abramo, 2013b.

FAGNANI, E.; FONSECA, A. (Orgs.) Políticas sociais, universalização da cidadania e desenvolvimento: educação, seguridade social, infraestrutura urbana, pobreza e transição demográfica. São Paulo: Fundação Perseu Abramo, 2013b.

. (Orgs.) Politicas sociais, universalização da cidadania e desenvolvimento: economia, distribuição da renda e mercado de trabalho. São Paulo: Fundação Perseu Abramo, 2013a.

FLEURY, S. Não é só a reforma política, são os direitos sociais! Plataforma Politica Social. 30/7/2013. Disponível em: <www.politicasocial.net.br>.

FONSECA, A.; JACCOUD, L.; KARAM, R. Do Bolsa-Família ao Brasil sem miséria: o desafio de universalizar a cidadania social. In: FAGNANI, E.; FONSECA, A. (Orgs.) Politicas sociais, universalização da cidadania e desenvolvimento: educação, seguridade social, infraestrutura urbana, pobreza e transição demográfica. São Paulo: Fundação Perseu Abramo, 2013b.

FONSECA, P. C. D; HAINES, A. F. Desenvolvimentismo e política econômica: um cotejo entre Vargas e Perón. Economia e Sociedade, v. 21, Número Especial, dez./2012.

FONTANA, H. O PT e a reforma política. Teoria e Debate, 2013. Disponível em: <http://www.pt.Org.br/artigos/view/o_pt_e_a_reforma_ politica_por_henrique_fontana\#sthash.QhZRmSlH.dpuf>.

FURTADO, C. Brasil: da república oligárquica ao Estado militar. In: FURTADO, C. (Org.) Brasil: tempos modernos. Rio de Janeiro: Paz e Terra, 1979.

GRZYBOWSKI, C. Rio+20: não deixemos passar a hora! Publicado em 22/08/2011 no site <www.ibase.br> e <rio20.net>. <http://www.grap. org.br/2011/08/25/rio20-nao-deixemos-passar-a-hora-por-candidogrzybowski/>.

HELLER, L. Saneamento básico: a dívida social crônica e persistente. In: FAGNANI, E.; FONSECA, A. (Orgs.) Políticas sociais, universalização da cidadania e desenvolvimento: educação, seguridade social, infraestrutura urbana, pobreza e transição demográfica. São Paulo: Fundação Perseu Abramo, 2013b.

HIRSCH, J. O fim da democracia liberal. Publicado inicialmente em <www.links-netz.de>. Trad. Luciano C. Martorano para o portal 
Grabois: <http://grabois.Org.br/portal/revista.int.php?id_sessao=21\&id_ publicacao $=1190 \&$ id_indice $=3878>, 2013$.

IBARRA, A. Mercado de trabalho brasileiro: identificação dos problemas e propostas de enfrentamento na perspectiva da agenda socialdesenvolvimentista. In: FAGNANI, E.; FONSECA, A. (Orgs.) Politicas sociais, universalização da cidadania e desenvolvimento: economia, distribuição da renda e mercado de trabalho. São Paulo: Fundação Perseu Abramo, 2013a.

JACCOUD, L. Igualdade e equidade na agenda da proteção social. In: FAGNANI, E.; FONSECA, A. (Orgs.) Políticas sociais, universalização da cidadania e desenvolvimento: educação, seguridade social, infraestrutura urbana, pobreza e transição demográfica. São Paulo: Fundação Perseu Abramo, 2013b.

KHAIR A. Prioridade à Justiça Tributária. Carta Social e do Trabalho, n. 8 , jan.-ago./2008, p. 10-20.

KREIN, J. D. Balanço da reforma trabalhista do governo FHC. In: PRONI, M.; HENRIQUES, W. (Orgs.) Trabalho. Mercado e sociedade. O Brasil nos anos 90. São Paulo: Unesp; Campinas: IE-Unicamp-Cesit, 2003.

LAVINAS, L. Notas sobre os desafios da redistribuiçẫo no Brasil. In: FAGNANI, E.; FONSECA, A. (Orgs.) Políticas sociais, universalização da cidadania e desenvolvimento: economia, distribuição da renda e mercado de trabalho. São Paulo: Fundação Perseu Abramo, 2014A. . 21st Century Welfare. New Left Review, NRL 84, nov.-dez./2014.

MARICATO, E. Cidades no Brasil: neodesenvolvimentismo ou crescimento periférico predatório? Política Social e Desenvolvimento, n. 1, revista digital, 2013.

MENEZES, C. Quem pode virar o jogo político no Brasil? Canal Ibase, 16/07/2013.

MENEZES, F.; CAMPOLINA, A.; ROMANO, J. Segurança alimentar e nutricional: balanço e novos desafios. In: FAGNANI, E.; FONSECA, A. (Orgs.) Políticas sociais, universalizaçāo da cidadania e desenvolvimento: educação, seguridade social, infraestrutura urbana, pobreza e transição demográfica. São Paulo: Fundação Perseu Abramo, 2013b.

MERCADANTE, A.; TAVARES, M. C. Eixos de um novo modelo. Debate: Um outro Brasil é possível. Teoria e Debate, n. 49, 2001.

NASSIF, M. I. Não tenham medo dos jovens. Apenas os escutem. GGN, 18/06/2013. 
OLIVEIRA, Tiago. Subdesenvolvimento e mercado de trabalho no Brasil: impasses e desafios atuais. In: FAGNANI, E.; FONSECA, A. (Orgs.) Políticas sociais, universalização da cidadania e desenvolvimento: economia, distribuição da renda e mercado de trabalho. São Paulo: Fundação Perseu Abramo, 2013a.

PT. Partido dos Trabalhadores. Resolução política do Diretório Nacional. 20/03/2014.

POCHMMAN, M. Tributação que aprofunda a desigualdade. Carta Social e do Trabalho, n. 8, jan.-ago./2008.

RIBEIRO DE OLIVEIRA, A. T. Os desafios ao desenvolvimento econômico e social colocados pela dinâmica demográfica. In: FAGNANI, E.; FONSECA, A. (Orgs.) Políticas sociais, universalização da cidadania e desenvolvimento: educação, seguridade social, infraestrutura urbana, pobreza e transição demográfica. São Paulo: Fundação Perseu Abramo, 2013b.

ROCHA, S. Educação de qualidade e democrática: um direito de todos. In: FAGNANI, E.; FONSECA, A. (Orgs.) Políticas sociais, universalização da cidadania e desenvolvimento: educaçâo, seguridade social, infraestrutura urbana, pobreza e transição demográfica. São Paulo: Fundação Perseu Abramo, 2013.

ROMAMO, J.; CAMPOLINA, A.; MENEZES, F. Agricultura familiar e reforma agrária na superação da pobreza e na construção de um novo projeto de desenvolvimento rural. In: FAGNANI, E.; FONSECA, A. (Orgs.) Políticas sociais, universalização da cidadania e desenvolvimento: economia, distribuição da renda e mercado de trabalho. São Paulo: Fundação Perseu Abramo, 2013a.

SADER, E. Eles e nós: para a hegemonia pós-neoliberal. Carta Maior, 04/03/2014.

SALVADOR E. Reforma tributária desmonta o financiamento das políticas sociais. Carta Social e do Trabalho, n. 8, jan.-ago./2008, p. 20-26.

SINGER, A. V. A política como ela é. Folha de S.Paulo, 30/03/2014. . Esquerda ou direita? Folha de S.Paulo, 22/06/2013.

SKIDMORE, T. E. Brasil: de Castelo a Tancredo. 3. ed. Rio de Janeiro: Paz e Terra, 1989.

SPOSATI, A.; CORTES, L.; COELHO, R. P. S. Assistência social, seguridade e cidadania. In: FAGNANI, E., FONSECA, A. (Orgs.) Políticas sociais, universalização da cidadania e desenvolvimento: educação, seguridade social, infraestrutura urbana, pobreza e transição demográfica. São Paulo: Fundação Perseu Abramo, 2013b. 
STEDEILE, J. P. 30 anos do MST. Entrevista. O Estado de S.Paulo, $19 / 01 / 2014$.

TONELLI VAZ F. J. Longe do ideário de justiça tributária: simplificação com riscos para a seguridade social. Carta Social e do Trabalho, n. 8, jan.ago./2008.

VIANA, A. L. D.; SILVA, H. P; LIMA, L. D.; MACHADO, C. V. O sistema de saúde brasileiro: dilemas atuais. In: FAGNANI, E.; FONSECA, A. (Orgs.) Politicas sociais, universalização da cidadania e desenvolvimento: educação, seguridade social, infraestrutura urbana, pobreza e transição demográfica. São Paulo: Fundação Perseu Abramo, 2013b.

WALTENBERG, F. Igualdade de oportunidades educacionais no Brasil: quão distantes estamos e como alcançá-la? In: FAGNANI, E.; FONSECA, A. (Orgs.) Políticas sociais, universalização da cidadania e desenvolvimento: educação, seguridade social, infraestrutura urbana, pobreza e transição demográfica. São Paulo: Fundação Perseu Abramo, 2013b.

WERNECK VIANNA, L. O movimento da hora presente. O Estado de S.Paulo, $18 / 06 / 2013$. 